\title{
Entrepreneurship and Nation Building in a Changing Environment
}

\author{
Bassey Ubong \\ Federal College of Education(Technical), \\ Omoku-Rivers State, Nigeria
}

\section{Doi:10.5901/mjss.2013.v4n16p115}

\begin{abstract}
This paper is an argument for the review of Nigeria's national thinking to position the country for rapid socioeconomic development. The paper argues for a positioning of entrepreneurship as the locus of development effort at the national level. Although in a globalized world academic thinking should be universal, Nigeria is used as focus with the understanding that the position herein is applicable elsewhere particularly in developing countries which should better be described as poor countries, or at best, the old but more appropriate term "less developed' countries. Describing them as 'growing' countries would probably tell a better story, only that one has no idea when they will mature - if ever.
\end{abstract}

Keywords: Entrepreneurship,Development,globalization, policy

\section{Introduction}

If we fall back on history, it is clear that a faster route to massive socio-economic development of nations came about through the entrepreneurial route. The first mass development in modern history was during the Industrial Revolution in Europe of the $18^{\text {th }}$ century. Even feudalism and mercantilism were private-sectorbased. In the late $20^{\text {th }}$ century, Chinese governments recognized this fact and thus tactically moved away from centralized economic management. The subtle but real permission granted private entrepreneurs for a period of about three decades made it possible for that country of over one billion people to overtake Japan and become the world's second largest economy in 2010.

A former World Bank Chief Executive, Mr. J. D. Wolfensohn is so convinced that education is the core of any development effort that he states, "No country has succeeded without educating its people; education is the key to sustaining growth and reducing poverty" (2000, p. 67). Ito (1997) agrees, and submits that several studies of the rapid development of the famed 'Asian Tigers' - South Korea, Taiwan, Hong Kong, Singapore - point to the fact that the basis of their growth has been the emphasis on human capital development. There can be no doubt that in the $21^{\text {st }}$ century, any country that hopes to achieve rapid socioeconomic transformation has to tread the path of entrepreneurship or stay at the bottom of the ladder as a Heavily Indebted Poor Country (HIPC). HIPCs are 39 developing countries with high levels of poverty and debt overhang which make them eligible for special assistance from the World Bank and the International Monetary Fund (IMF).

\section{Basic Concepts}

National Development - this work sees national development as the ability of a nation to continually improve the welfare or quality of life of its people in indices such as education, economics, health, recreation, and so on.

Entrepreneurship - is the art, science, and act of generating business ideas, developing them, and managing them successfully. An entrepreneur who is the basis of the concept of entrepreneurship and the 
person or organization or group that drives entrepreneurship, is that agent of change that has the characteristics of innovativeness, ability to organize and manage resources, the staying power, readiness to take risks, and the profit drive.

Philosophy of Education - this refers to intellectual efforts that dwell on the nature, aims, and problems of education. At a national level, the philosophy of education is part of the national policy on education which is a policy framework that spells out the direction, thrust, and emphasis that a nation places on the process of educating of its citizens.

\section{Country Profile - Nigeria}

The United Nations Children's Fund (2010) describes Nigeria as a 'fragile' nation because of insecurity, crises, and poor governance. A report by the World Bank (1996) opens with the disturbing words, "Nigeria presents a paradox. The country is rich but the people are poor." A former United States Assistant Secretary of State for African Affairs in President Bill Clinton's administration, Dr. Susan Rice (currently the United States Ambassador to the United Nations) re-echoed this in what has turned out to be a famous aphorism, "Nigeria is too rich to be poor and too poor to be rich." Such conflicts and contradictions epitomize the world's $6^{\text {th }}$ largest producer of crude petroleum, the so-called 'black gold' and the $10^{\text {th }}$ on the chart with the largest proven reserves.

UNICEF (2005) put Nigeria's population in 2005 at 128,709,000 of which the under 18 age group constituted $66,211,000$ or $51.44 \%$. This is a sizeable proportion that should attract specific policies to cater for them, of which education should be the most important. Rather, only 3\% of Federal Government expenditure on the average went to education between 1993 to 2004 as against 26\% recommended by UNICEF. The organization also recorded that the percentage share of national income going to the lowest $40 \%$ of the population between 1883 and 2003 was 13\% while the highest $20 \%$ of the population carted home $56 \%$ of the nation's wealth. Life expectancy was a low median of 43 years. Nigeria's population has since grown to about $170,123,740$ as indicated by CIA Fact Book (Theodora, 2012).

UNICEF also indicates that for the period 1993-2003, the proportion of Nigerians on less than $\$ 1.00$ per day income was 70\%. By 2007 it was put at 71\%. The United Nations Population Fund (2006) states that the per capita gross national income (GNI) of Nigeria was $\$ 900$ in 2003 while that of neighbouring Ghana was $\$ 2$, 190 and that of South Africa was $\$ 10,270$. Although Nigerians are, according to politicians of the day, said to be reaping the 'dividends of democracy,' poverty on a wide scale is still very evident. It is probably this realization that informed the institution of the Poverty Alleviation Programme (PAP) by the Federal Government a few years back. The PAP, evidently an aspect of the National Poverty Eradication Programme (NAPEP), paid out N3, 500.00 to some youths from a budgetary allocation of N10 billion in the year 2000.

Prior to the PAP, related programmes included the Directorate for Food, Roads \& Rural Infrastructure (DFRRI, launched in 1986), the National Directorate for Employment (NDE, established in 1986), Better Life Programme (BLP, from 1987), the Family Support Programme (FSP, from 1994), and Family Economic Advancement Programme (FEAP, from 1997), To solve the problem of finance that has been a major constraint in self-development for many Nigerians, special banks were established by the Federal Government. These included the People Bank of Nigeria (PBN, established in 1989), Community Banks (CB, established in 1990). The banks and FEAP were expected to focus on provision of credit facilities for the development of cottage industries while NDE was to concentrate on training and subsequently, provision of loans to ensure that those trained start their own businesses.

While these programmes were well intentioned, they often ended up being mired in controversy emanating from mismanagement of funds. The programmes appeared to alleviate the poverty of the managers or administrators rather than that of the target group - the poor, and particularly the youths. Rather than palliatives therefore, it is proposed that a more sustainable approach would be to train and equip Nigerian 
youths to enable them develop their own businesses. This would, through a multiplier processes, be more beneficial to the national economy than stipends.

Although Nigeria is not one of the 34 African countries in this unfortunate group, the country ranks 156 th out of 185 in the United Nations Development Programme (UNDP) 2011 Human Development Index (HDI) in spite of being the worlds $6^{\text {th }}$ largest exporter of the unsustainable resource known as crude oil. HDI is a standard international comparative measure of well-being and quality of life using three indices - life expectancy, literacy, and standard of living. To stay away from the HIPC group and to achieve rapid national development, we argue that a more sustainable approach would be entrepreneurial nationhood by making entrepreneurship the cornerstone of the National Policy on Education (NPE).

\section{Entrepreneurship Dynamics}

Entrepreneurship as earlier defined is simply what entrepreneurs do. We have also identified the salient characteristics of entrepreneurs. It is also important to note that entrepreneurship is a process, that is, it takes place in stages.

\section{Entrepreneurship and Economic Development}

A lot of intellectual efforts have been advanced in the direction of establishing the link between entrepreneurship and economic development. The Global Economic Monitor (GEM), a research organization supported by the Babson College, Massachusetts, USA and the London Business School, London, is devoted to the study not only of the relationship between entrepreneurship and economic development but also on how entrepreneurship can be cultivated particularly in developing countries. An annual study of up to 42 countries is carried out by GEM and the results published for world consumption.

Hisrich and Peters (1998) hold that the link between entrepreneurship and economic development arises from the fact of increasing per capita output and income as well as "initiating and constituting change in the structure of business and society" (p. 13). These authors indicate that in many countries, rundown areas or communities have been energized through entrepreneurship programmes.

One of the pioneering and greatest names in entrepreneurship was Professor Joseph Schumpeter (1883-1950), an Austrian-American economist. Schumpeter extolled entrepreneurship and used the famous phrase "creative destruction" in his analysis. He argued that entrepreneurs play a critical role in capitalist economies by way of stimulating business through financial investment and innovation. Entrepreneurs create new products, services, and methods as they innovate and in the process, destroy old products, services, and methods. This pushes forward the development process. Samuelson and Nordhaus (1998) also note that Schumpeter challenged the glorification of perfect competition at the time, arguing that the essence of economic development is innovation and that monopolies are the wellsprings of innovation in a capitalist economy.

Entrepreneurship appears to have worked wonders in developed countries. Strom (2011) reviews the place of entrepreneurship in the developed world and declares:

We know that innovative entrepreneurs - those who bring new products and processes to the market - are disproportionately responsible for the breakthrough or 'disruptive' innovations that change our daily lives and allow for the rapid improvement in standards of living that developed countries have experienced over the past century, and also disproportionately responsible for job growth in industrialized economies.

In developing countries, Strom (2011) is not as confident as he is in the statement above. He notes that in developing countries, the problem is "more complex" because of the common approach of using developed 
country paradigms as bases of analysis. He recommends in his conclusion:

While there will never be a 'one size fits all' public policy solution, continued research examining the relationship between entrepreneurship and growth and policy prescriptions to promote an innovation driven, entrepreneurial economy are a big step in the right direction.

In the process of examining the place of entrepreneurship in economic development, Naude (2011) sees three groups of nations - the developed, the emerging economies, and the developing countries. For the first group, he submits:

Global development is entering a phase where entrepreneurship will increasingly play a more important role. There are at least three reasons for this, each particular to certain types of countries. Firstly, in the West, the managed economy of the 1970s-2000s, characterized by reliance on big business and mass production, has given way to a socalled entrepreneurial economy. Here knowledge-driven goods and services are now more flexibly provided by smaller firms, and the emergence of a creative class requires a less interfering but more facilitating state.

In the emerging countries, most notably the ones described with the acronym BRICs - Brazil, Russia, India, and China, Naude (2011) notes that "impressive growth has been driven by a veritable entrepreneurial revolution. The need in these economies to sustain growth through sustainable access to resources, knowledge, markets, and low-carbon industrialization puts a premium on innovative entrepreneurship." In the third group, Naude (2011) declares:

Finally, in the least developed countries, where aid dependency is high, donors have been shifting the emphasis in development cooperation towards private sector development ... In many of these countries, including resource-poor North African countries, populations consist of many young people who see little prospects of gaining employment with decent wages. Promoting youth entrepreneurship here has become a vital policy objective of many development organizations and donors.

Naude (2011) concludes in the study sponsored by the United Nations University's World Institute for Development Economics Research (UNU-WIDER) in Helsinki, Finland that entrepreneurship has the capacity to spur economic growth and that economic development and entrepreneurship work hand in hand even if the later could generate some unhappiness in the populace along the line. Renjith (2009) simply concludes that "the development of entrepreneurship is inevitable in the economic development of a country. The role played by entrepreneurship development can be expressed in the following words 'economic development is the effect for which entrepreneurship is a cause."'

Ahiauzu (2010) has done some work on what should be the role of entrepreneurship in the economic development of Nigeria. First, he quotes Dejardin (2000) who asserts that "an increase in the number of entrepreneurs leads to an increase in economic growth" (p. 286). This is supported by Morrison (2000) who declares that "Throughout history, entrepreneurship has been found to be important and meaningful in society at points of transition, for example, traditional to modern, modern to post-modern, and statecontrolled economies to free market" (p. 290). Asc (2006) as also quoted by Ahiauzu (2010) asserts that there is a positive relationship between entrepreneurship and economic growth while Henderson (2007) states: 


\begin{abstract}
Entrepreneurship is increasingly being recognized as a primary engine of economic growth. By combining existing resources with innovative ideas, entrepreneurs add value through the commercialization of new products, the creation of new jobs, and the building of new firms. The Global Economic Monitor indicates that nations with higher levels of entrepreneurial activity enjoy strong economic growth. In short, entrepreneurs are the link between new ideas and economic growth (p. 2).
\end{abstract}

It is pertinent to state that the writer quoted above, Z. Asc, is the Chairman of the GEM Consortium, a worldwide research organization on entrepreneurship. The annual research by GEM has consistently shown a positive relationship between entrepreneurship and economic growth. It is also pertinent to mention that economic growth, while not synonymous with economic development, explains about the same thing. Economic development is an extension of economic growth in that the latter is interested in the diffusion of the benefits of growth to citizens while the former looks at changes in socio-economic indices in society (upward changes) such as the Gross Domestic Product (total value of goods and services produced within a country at a point in time) or Gross National Product (total value of goods and services produced by nationals of a country irrespective of where they are).

Ahiauzu (2010) presents information on Total Entrepreneurial Activity (TEA) tests and comparisons that show that Africa produced the country with the highest national level of entrepreneurial activity in 2003. This country was Uganda and although that country is still poor, such an index placed it among the nations with very high growth potentials. Finally, based on his analysis, Ahiauzu (2010) states that one can "confidently conclude that entrepreneurship and economic development are largely inseparable, especially in developing countries" (p. 293).

With respect to Nigeria, he submits that because of absence of valid empirical evidence as well as the sustained euphoria generated by crude oil revenues, the role of entrepreneurship on economic development in the country cannot be established. He however calls on policy makers, political leaders, and business leaders to encourage a national debate on "a truly Nigerian economic system based on our traditional value systems and philosophies, which will be applied to enable the Nigerian people to better understand the processes involved in providing a truly supportive environment for enterprise development" (p.293).

The best system, Ahiauzu (2010) recommends, is "an entrepreneurial state that is first concerned about the development of a collective entrepreneurial consciousness at all levels of society" (p. 293). The development of an entrepreneurial consciousness, this work submits, should be by way of enshrining entrepreneurship in the National Policy on Education as Nigeria's primary national philosophy of education. The "collective consciousness" is seen in the context of this work as neoteric-Calvinism, in which all citizens of the future are made to develop an entrepreneurial outlook fostered in the formal and non-formal school system (Ubong, 2012).

\title{
Entrepreneurship Education
}

It is the opinion of Oranu (1998) that "if there exists any one fairly universally accepted objective of education, especially occupational education, that objective is that of self-reliance." One branch of education which is capable of developing self-reliance in learners is business education which Nannasy (1970) in Esene (1997) defines as that aspect of education which provides the knowledge, skills, understanding, and attitudes which learners require for effective performance in the business world as producers or consumers.

Entrepreneurship education is part of entrepreneurship development. Entrepreneurship development involves the selection of persons with requisite and identifiable entrepreneurship skills for development and equipping them with management techniques to enable them optimally manage businesses either for self or for others. Identification of persons with skills is a key ingredient because not all persons that are interested in going into business are entrepreneurs. Entrepreneurs have special characteristics such as innovativeness 
(Amaewhule and Eni, 1994) and risk taking (Paul, Ickis, and Levitisky, 1989). To be added to these is tenacity or staying power, because the world of business is so volatile that only those who can solidly manage the swings - booms and recessions - end up as successful businesspersons. Such persons can be found at the high or low strata of a society. However for entrepreneurial education to be effective, a minimum level of education is a sine qua non because illiterate or semi-literate persons may find some business management terms and principles difficult to comprehend. The minimum entry qualification for artisans should be the First School Leaving Certificate (FSLC); for craftsmen, Junior Secondary School Certificate (JSS3); while technicians should enter for training with the Senior Secondary Certificate (SSCE).

Thinkers such as William Petty, Montesquieu, Henry Thomas Buckle, and John Keats have noted the affinity between Protestantism and the development of commercialism (Kim, 2007) and a study using the perspective - literacy - found a strong correlation between literacy induced by Protestantism and economic growth. Kortayev, Malkov, and Khaltourina (2006) empirically established a strong correlation between early introduction of literacy and capitalist development. This is also the position of Bosma, Kent, Autio, and Levie (2007) and the various research publications of the Global Economic Monitor (GEM) over the years.

\section{Philosophical Foundations of Entrepreneurship}

There are several underlying principles or philosophies that inform the concept of entrepreneurship. Philosophy in antiquity was based on two principal schools of thought - idealism and realism. Idealism, generally identified with Plato, holds that there can be no true knowledge based on sense experience as what we see are but copies of what is in the spiritual and can only be known through mental processes. Realists on the other hand believe that the world is real and can be known through sense experience.

Of particular relevance to entrepreneurship is pragmatic realism which includes experimentalism. Okoh (2003) indicates that "Pragmatism stresses action and doing and maintains that imaginative theorizing must be supported and controlled by the outcome of active experimentation" (p. 36). Pragmatism, an offshoot of empiricism, is the dominant educational philosophy of the USA, having been canvassed by philosophers $\mathrm{C}$. S. Peirce, John Dewey, and William James. Pragmatism is behind the mammoth growth in entrepreneurship in the USA that has made the country the number one economy in the world. In 2010, China overtook Japan to become the world's second largest economy. This feat was achieved because of liberalization of the economic sector. In the era of strict state control when entrepreneurship was suppressed, China remained a poor economy.

Humanism also has a relationship with entrepreneurship, which leads to self-reliance. Entrepreneurship emphasizes individual action that will lead to self-determination and self-sufficiency. Mautner (2000) presents two viewpoints on the concept of humanism from two language groups. The English-speaking world from the $19^{\text {th }}$ century saw humanism as a non-religious worldview "usually based on a belief in man's capacity for selfcultivation and self-improvement, and in the progress of mankind" (p. 256). Contemporary philosophy in the French-speaking world sees humanism as "a conception of man as an autonomous being, capable of selfdetermination, together with the assumption that an individual's choices can make a real difference to a society or to a course of history" (p. 256). Both self-cultivation and self-improvement are aspects of entrepreneurship.

Another philosophical foundation of entrepreneurship include individualism which makes the individual its focus and so starts "with the fundamental premise that the human individual is of primary importance in the struggle for liberation" (Encyclopedia Britannica Online, 2011). Natural rights and freedom are the substance of these theories. Classical liberalism (including libertarianism), existentialism, and individualist anarchism are examples of movements that take the human individual as a central unit of analysis (Brown, 1993). Economic individualism is central to entrepreneurship because it canvasses economic independence.

Liberalism is another philosophical principle that is germane to entrepreneurship; it is the belief in the importance of the freedom of the individual. Liberalism is also regarded as a set of ideas in social and 
political thought that emphasize the value of individual right, freedom of choice, and freedom from interference while the role of the state should be limited to the protection of such rights (Mautner, 2000).

Libertarianism is a related concept, an aspect of political philosophy that advocates the maximization of individual liberty and the minimization or even abolition of government (Vallentyne, 2006). Viewpoints on libertarianism range from pro-property to anti-property, and from minarchist to openly anarchist (Zwolinsky, 2008) as well as egoism (Ridgely, 2008). Libertarians hold that resources may be appropriated by those who discover and develop them even without the consent of others.

The philosophical foundation of entrepreneurship would not be complete without mention of the concept of laissez faire which is of French origin with the simple meaning "let (the people) do." In essence, people should be allowed to do for themselves what they would although within the ambit of the law. Scottish economist Adam Smith used the concept in his thoughts on the role of the 'invisible hand' of the market. David Ricardo and John Stuart Mill, both British economists, developed Smith's laissez-faire theory further. State control of economies have continued to the contemporary time; however, the "basic individualistic appeal of the laissez-faire philosophy ... still exists today in the emphasis placed on the profit motive and on individual initiative in economic progress" (Encarta Encyclopaedia, 2008). Initiative and the profit drive are two important characteristics of entrepreneurs and entrepreneurs.

\section{Are Entrepreneurs Born or Made?}

Aristotle in Politics and expanded in Nichomachian Ethics tells us that man can be made good by education, the 'good' coming in various forms that have the ultimate focus of attainment of individual happiness. Thus education can play a central role in the development of the individual for attainment of individual and group goals.

Angeliki Frangou is a Greek billionaire who has made a fortune in the shipping business. In an interview in Cable News Network (Anderson, 2013) she stated without hesitation, "Shipping is in my DNA." She was referring to the fact that she is from a long line of shipping magnates in Greece. It is related that this woman borrowed \$2 million dollars to buy an old ship in the 1980s. She now runs a fleet of about 100 ships in the Navious Group that is worth \$4billion (about N640 billion). This raises the question whether entrepreneurs are born or made (and whether this writer has entrepreneurship in his DNA, given the fact that his father was a businessman till he died. There are three perspectives that can be briefly discussed here:

1. The tabula rasa argument. If a child is born on a null intellectual tablet, then whatever a child knows after birth is courtesy of what is written by self and others on that blank slate. Thus even the activity of grabbing and squeezing a particular part of the female body can generate nutrient from day one is regarded as impulse, not knowledge. The tabula rasa argument was put forward by British philosopher John Locke (16321704) who espoused the theory in his magnum opus, An Essay Concerning Human Understanding published in 1690. This work is regarded as having signalled the birth of empiricism although Francis Bacon is said to have muted the idea earlier.

A child's system is regarded as a blank slate of which experience imprints knowledge and innate conceptions have no place (Encarta, 2008). The Lockian position is regarded as the classic 'nurture' argument: everything a human being knows is a product of experience - this is regarded as the basis of empiricism of which Jon Locke is regarded as founder and chief proponent. Scottish philosopher David Hume (1711-1776) also espoused this philosophy.

The flipside is rationalism, canvassed by French philosopher René Descartes (1596-1650), Dutch philosopher Baruch Spinoza (1632-1677), and German philosophers Gottfried Wilhelm Leibniz (1646-1716) and Christian von Wolfe (1679-1754). Rationalists argue that reality can be established through reason, without recourse to experience. German philosopher Immanuel Kant attempted a synthesis recognizing knowledge as deriving principally from experience while intuition or reason can be structured into experience. 
Some neuroscientists particularly those of the distributive school appear to disagree with the blank slate concept. Nicolelis (2011) argues that the brain "accumulates evolutionary and individual life history" (p. 26); based on this, he argues that the Cartesan assumption that the brain is a passive interpreter or decoder of signals external to it is against research evidence. René Descartes was a prolific French philosopher of the $17^{\text {th }}$ century.

The tabula rasa concept can also be questioned on the basis of genetics. The gene is the basic unit of heredity found in the cells of all living organisms that ensures transmission of characteristics from one generation to the next. The controversy as to the level of contribution between genes and environment continues although newer studies are looking at the possibility of existence of a particular gene that affects intelligence for instance. However, others such as muscle strength or musical achievement seem to require contributions from both genes and the environment. If a person is born with the alleles for great athletic or musical potential, for example, those talents will not develop without practice. A child may be born with the alleles for potentially high academic intelligence, but lack of stimulation and limited exposure to new experiences in early childhood may keep the child from realizing that potential (Encarta, 2008).

The question is: if genotype affects intelligence and genes of any individual is taken from two parents, how come all the offspring of a pair of parents do not display equivalent capabilities? Meanwhile the tabula rasa argument appears to be interesting when the law of excluded middle is brought into the field of play. This law of thought holds that anything must either be one thing or the other; it is either A or not A. Human beings cannot come into the world without any in-built traits and at the same time come in with some in-built traits.

2. Chance entrepreneurship - In a number of cases that may not be documented, some people go into business development because they have no other option. Two cases easily come to mind. First, a person that suddenly finds himself or herself out of paid employment for whatever reason other than planned retirement, could decide to venture into the business world if paid job options are not available particularly in the current world where jobs are so few are in fact becoming fewer even in the most economically developed countries. Spain for instance is witnessing $25 \%$ unemployment rate among youths who have energy and drive. Rather than rot at home or join demonstrators, a person can decide to use available resources and venture into business. Second, is the case of women whose husbands are well to do and would prefer if their wives stayed at home to take care of their children. A woman that abhors laziness can request the husband to open a shop in the family garage or build a kiosk in the premises to enable her run a small grocery or personal service business such as hair dressing. Both cases can be regarded as chance entrepreneurship because the persons did not see entrepreneurship as a way of life originally. Persons in this group may drop the business idea if a job becomes handy.

3. Entrepreneurs born, and made - One of the laws of thought is termed the law of excluded middle. The law states that anything must either be A or not A, that is, given two contradictory propositions - "A" and "not A," it must be either one or the other. For example, the two propositions, "There is an Inaugural Lecture at the Multipurpose Hall" and "There is no Inaugural Lecture at the Multipurpose Hall," one must be true and the other untrue. Traditionally this implies a two-parameter (true-false value) in logic. Jan Lukasiewic, a twentieth century logician extended this understanding to include a third value - 'possible' - now described as ternary or multivalued logic.

Given our proposition "entrepreneurs are born, not made" or the alternate, "entrepreneurs are made, not born," the subject is 'entrepreneur' in the two cases while the predicates are "born, not made" and "made, not born" respectively; the two are contradictory propositions. In the first instance, by the Kantian model, the two propositions are synthetic a posteriori which implies that the predicate concept is not contained in the subject concept and justification of the proposition relies on experience. If the ternary model is introduced, a 
third variant can be adduced: "Entrepreneurs are born, and made." This is a synthetic a posteriori proposition. We can, with this modified proposition, argue:

a) That entrepreneurship can be natural or innate to the individual. This would run against the tabula rasa principle enunciated by John Locke. However, as already argued, research has indicated, even if not confirmed, that human beings at birth appear to start life with some learned behaviours. This might agree with our traditional believe in reincarnation.

b) That entrepreneurship can be induced through various ways, and in the context of this paper, through education.

c) That a) and b) can be regarded as a possibility, that is, entrepreneurship is innate, and can be induced, in which case he or she that is born an entrepreneur can have the skill honed say, through education. We adopt this third option in this paper.

It is important to note the role of the conjunction 'and' in the proposition. In grammar, a conjunction is a connecting word or something that has simultaneous occurrence; in logic, it implies a compound statement as in a proposition in which the parts are true only if both parts are true individually. Thus the proposition ' $A$ ' and ' $B$ ' is true if $A$ and $B$ are true. This implies, from our modified proposition, that for "entrepreneurs are born and made" to be true, the "entrepreneurs are born" and "entrepreneurs are made" must both be true. If we accept the argument put up by Nicolelis (2011) and the argument that men are made good by education, we can accept the proposition that all human beings have innate in them, the entrepreneurship traits and that such traits can be sharpened or developed through education, specifically, entrepreneurship education.

\section{Entrepreneurship for whom?}

\section{Entrepreneurship for Women}

It is necessary to dwell on this group because empowering women is empowering families and the whole society, much more than men. It is also important because generally speaking, the potentials of this group are lost or very poorly developed in most societies. Women are involved in business undertakings but in poor societies, they are predominantly in micro businesses such as petty trading and small scale farming.

Entrepreneurship is not expected to be gender sensitive although it appears that a strong bias still exists across the globe against women entrepreneurs. Cable News Network (CNN) has for some time been running a series on distinguished women particularly in the business world. One edition (CNN, 2013) focused on Güler Sabanci who is running the Sabanci Holding, a \$25 billion (about N4 trillion) family business in Turkey. This very successful lady who runs a highly diversified business group that includes manufacture, services, and banking as well as a private university and a museum of arts narrated her experience as she tried to attend a dinner for bankers in London in 1985. She was denied entry because the forum has been regarded as an all male club. Meanwhile London is often regarded as the world's leading finance centre.

Ball, McCulloch, Jr., Frantz, Geringer, and Minor (2002) writing on sexism in countries with respect to participation of women in the work force and in business, state:

Acceptability of women as full participants in the work force ranges from improving acceptability in the United States and Western Europe to almost no acceptability in many countries. While sexism is far from being eliminated, the United States has seen large strides in the status and acceptability of women in business. In other countries, however, laws, customs, attitudes, and religious beliefs continue to act as extremely hostile barriers to women in business (p.418). 
This situation is confirmed by Todaro and Smith (2003) and the World Bank (2008) among others. The Nobel Prize laureate in Economic Science, Professor Amartya Sen in reviewing the poverty situation among groups described the female group in Asia and Africa as "missing women." What is of prime concern to us in this work is the status of women in business not just as employees and managers but as business proprietors. What, one may ask, is the primary reason behind the bias against women for, even in the United States, it is President Barak Obama that signed an Executive Order to equalize the pay of men and women in the country in 2009? Hitherto, women professors for instance were earning less than male professors and the same situation obtained in other sectors of the economy.

Ubong (2003) went back to the story of creation from the biblical standpoint to attempt to explain the genesis of the problem. In a paper titled "The gender controversy, biblical account, status of women, and their empowerment" he submits that the discrimination against women is as old as creation based on the biblical position that God first created the male species of human being and no one knows how long it took the Creator to come out with the female given the fact that a thousand years in His sight is like just one evening. Nor are matters helped by the fact that woman by revealed truth came from just one rib of a man, and that Adam was given the privilege to give names to animals and plants before Eve arrived, the understanding here being that only a very mature being particularly in prehistoric time could have been able to name scores of animals without confusion or repeating names.

Wokocha (1995) is of the opinion that "culture is women's number one enemy in Nigeria." This is in line with the position of Ball et al (2002) earlier quoted. The World Bank (1995) states that in Nigeria, there is "feminization of poverty" in which the capacity of women to participate in the development process are constrained by systematic factors such as laws, customs, and denial of access to basic technologies and other resources that can conduce economic production. Nwosu-Izuwah (1999) describes the tendency of the society and women themselves to limit women to certain courses of study and vocations as "limited feminine fields." Interestingly, a study by Obi and Ali (1995) revealed that girls interviewed prefer male bosses to female bosses whether in the public or the private sector.

The problem of constraining women is so strong that the younger generation of the female gender is affected. In a study by Ubong (2001) on the attitude of female science students towards private participation of girls in business, it was found that a majority of those surveyed in the Federal College of Education (Technical), Omoku indicated their disinclination to adopt entrepreneurship as a lifetime engagement. A statistical test showed preference for employment vis-à-vis business by the girls that filled the questionnaires. Their reasons included fear of "stress" associated with business management, uncertainty associated with raising capital, and lack of knowledge of business management. The study however found that business education formally or informally could encourage girls to go into private business.

What is the way forward for women in entrepreneurship particularly in developing countries, when as Ubong $(2005,2006)$ submits, peace in the home would likely result from women that have their own sources of income? Is it sufficient to merely pontificate or go on advocacy only?

Several approaches have been used to encourage women to go into private business. In the USA, the Small Business Administration has a special programme for women entrepreneurs. Under the Women's Financing Section, loans below $\$ 50,000.00$ are guaranteed to qualified women in the context of the Women's Business Ownership Act of 1988. This implies that a specific law is in existence in the USA to encourage women participation in business, something that developing countries should learn from. The SBA also provides micro loans to women ranging from $\$ 100.00$ to $\$ 25,000.00$. Given the fact that finance is the about the most daunting problem for women entrepreneurs, direct action is required if women participation in business is to made a general practice.

The idea of microfinance was started by Professor Yunus in Bangladesh in 1986. His first target group was women, who were given loans as small as $\$ 2.00$ to start microenterprises. Experience has shown that repayment rate particularly among women borrowers range between $95 \%$ and $100 \%$. Professor Yunus and the 
Grameen Foundation won the Nobel Prize for Peace in 2006 for his work with women and other small borrowers.

In Nigeria, Ubong (2005) has suggested empowerment of women through entrepreneurship development. Entrepreneurship development consists of identifying persons who have the characteristics of entrepreneurs, training them, giving them access to enabling facilities such as business credit and marketing, monitoring, evaluation, and retraining as necessary. The following stages are relevant:

i) Preliminary processes - programme development, to include identification and analysis of all issues involved in business development for women including costs and benefits of effort.

ii) The Home Front - reorientation of the families and the society at large towards accepting women entrepreneurs without the negative feeling for instance that traveling and meet people to transact business could affect their fidelity and marital status. Employees (men and women) have to learn to accept women entrepreneurs as bosses. Obi and Ali (1995) as already noted, indicate that in a survey, it was found out that business education students (including girls) who were interviewed would rather not have women as bosses in organizations including business establishments.

iii) Training - well-articulated programmes for training of women entrepreneurs have to be designed. They should include theory and practice of business. For girls, the normal school environment should suffice. For adult women, out-of-school, conducive atmosphere is preferable. For instance, the Boston Center for Adult Education (2001) in the USA provides a relaxed and enjoyable setting for learning. The Center offers more than 500 courses in a wide range of subjects and specialties. In Canada, the Center for Entrepreneurship Education and Development (2003) of the Province of Nova Scotia runs an integrated curriculum that "works best when it is developed in an environment outside the traditional classroom. This allows for the freedom of individualized learning and facilitates the link between the educational process and economic reality." These are in contrast to the Nigerian situation where 'adult education' classes hold in dilapidated primary school classrooms and town halls.

iv) Support Services - this involves the provision of business enhancing services such as feasibility studies and business consultancy generally, credit facilities, market information, and access to business inputs, among other things. It also recognizes the need for periodic retraining and extension services at the incubation stage of the businesses and periodically given the rapid changes in the society in terms of tastes and preferences, technology, information, and related issues.

v) Monitoring, Mentoring, and Evaluation - sustained visits to new businesses in particular could help in managing emerging challenges that if not stitched in time, could lead to a loss of nine. Mentoring implies attaching specialist to specific entrepreneurs for hands on management activities.

\section{Out-of-School Group - Skills Acquisition}

A more reliable approach to poverty reduction is through education, and specifically, business or vocational education, which includes skills training. This is in line with the experiences of other countries of the world, particularly the emerging or newly developing countries of Asia. It is also in line with the Chinese saying that if a man is given a fish, he is fed for a day; but if he is taught how to fish, he is fed throughout life. Thus development efforts should focus on skill development and human capital formation rather than on provision of direct consumption goods or consumption assistance via poverty alleviation hand-outs.

Industry-academia partnership, as in the case of the Federal College of Education (Technical), Omoku and crude oil producing companies, need to be encouraged or possibly legislated. There could also be a threeway linkage among industries, institutions, and government in what is known as the triple helix model. This cooperation arrangement has been found to be useful in many countries (Klofsten, Jones-Evans,and Scharberg, 1999; Kankonen and Niemenen, 1999; Bunders, Broerse and Zwekhorst, 1999).

Two of the apparent post-training problems associated with skills acquisition in Nigeria include lack of follow-up and lack of material assistance for trained persons desiring to establish their own businesses. Every 
programme should have built in facilities for monitoring, evaluation, and retraining while assistance in the form of credit, marketing information, personnel matters, record keeping, and related management issues should be in-built in every skills programme. The recent introduction of a mentoring programme by Addax Petroleum for graduates of skills training is a good one and should be encouraged. The company is even experimenting on part disbursement of take-off funds so as to limit misuse of bulk funds advanced to the youths that are expected to use what they have been given to go into business development for self and others.

Very importantly, there must be proper policy coordination and consistency. Some of the problems of development in Nigeria include policy conflicts and policy instability. The Small Business Administration is an organ of the Federal Government of the United States of America. It coordinates matters related to small and medium scale enterprises. Developing countries such as Nigeria require such powerful organs to be able to stabilize the system (Ubong and Nyanabo, 2006).

\section{Youths}

The primary focus of this piece is the youth who are correctly regarded as the future of every nation. Chan (2005) tells us the way many governments are handling entrepreneurship education given its crucial nature. He submits:

.... some governments are rethinking the way the young are educated by infusing creative thinking and innovation in their nation's educational curriculum. In the same vein, they are putting much emphasis on the need to train future entrepreneurs through infusing entrepreneurship components within the educational option, especially at the tertiary level. Some countries have taken this initiative to a higher level by introducing entrepreneurship education at elementary school and encouraging them to be future entrepreneurs when they are of age.

Ubong (2001) suggests that a more sustainable approach to poverty reduction if not elimination is through encouraging youths, particularly those with identified entrepreneurial skills to go into private business particularly in science and technology because these have natural potentials for business development. He therefore called for reforms in the educational curriculum to prepare students for self-reliance.

\section{Children}

Although Swiss psychologist Jean Piaget's developmental stages recognizes age twelve as concrete operational stage during which children can engage in abstract thinking and mathematical reasoning which means they can handle business issues, it does not appear that it is right to expect children, at least the normal ones, to go into private business. It does not in any way give parents and guardians the permit to send their children to the market, particularly the ones on the road. Meanwhile, how many adults do we see weeping on the road as a result of loss of sales proceeds, whether the child genuinely lost the money or used it to eat?

The International Labour Organization (ILO) fixes age twelve for light work in paid employment and 16-18 years for hazardous jobs. Unfortunately in developing countries, Odaga and Henevel (1995) state that child labour is indispensable to the survival of some households, and schooling represents a high opportunity cost to those sending children to school" (p. 17). We argue that even at age 18, a young adult should be in school rather than in employment, and certainly not in private business that is suffused with uncertainty as well as mental, physical, psychological, and emotional hazards. What is more, the dangers involved in micro businesses such as street trading where cases of rape, abduction, motor vehicular accidents and other mishaps are not difficult to come by. Ubong (1999) has detailed the perils of street trading, the dilemma of parents involved in it, and the legal issues in Nigeria and the world at large. Children should be kept in school 
until they are mature enough to face the rigours of the business world. Free education and scholarships should take care of those unable to meet the financial expectations of school life.

\section{Scientists, Technologists, Technicians}

Ubong (2002) notes that it is evidently more reasonable to employ an engineer to head a technical organization than graduates of non-engineering or science disciplines. This is apparently the reason behind recruitment of engineers to head many of such organizations in Nigeria including the Nigerian National Petroleum Company (NNPC), Power Holding Company of Nigeria (PHCN), radio and television networks, and so on. However, it is necessary that such persons have in addition to technical knowledge, management skills in areas such as accounting, marketing, personnel, and so on. This is also why such persons go for management courses that lead to Master in Business Administration (MBA), diploma in business related courses, and several management workshops and seminars.

In a study by Ubong (2002) a statistically significant difference was observed with respect to engineers and technologists who hold the opinion that business training is necessary for successful operations as professionals and those who do not. It was also ascertained that most engineers and technologists in Nigeria have received no formal management training before heading organizations or departments in organizations. This is probably one reason many technical companies both private and public experience growth and profitability challenges. Out of 50 respondents comprising 29 COREN registered engineers, two architects, 6 technologists, and 10 technicians, the following were observed:

1. $94 \%$ indicated that there is a strong positive relationship between knowledge of business management and engineering functions.

2. $42 \%$ said they felt a sense of inadequacy in management whether in employment or in their private business engagements.

3. A wide disparity exists with respect to perception of critical areas of business knowledge for engineers. This ranged from 40 respondents for management to 6 for ability to prepare profit and loss account. The major areas of deficiency include budgeting, interpreting financial statements, finance and banking, and appreciation of audit reports.

Ubong (2002) therefore recommended that in designing the curriculum for science and technology, business education courses such as accounting, management, marketing, finance and banking should be recognized. The University of Nigeria (2010) has many entrepreneurship courses in technical/vocational education programmes under the auspices of the Centre for Entrepreneurship and Development Research. Other institutions of higher learning should consider this.

\section{The Niger Delta Region (NDR)}

Outside Nigeria, the NDR is known more for youth restiveness and kidnapping of oil company workers than for anything else. With increased security being arranged for oil company workers, the NDR youths have since turned attention to less financially endowed Nigerians probably with Omoku currently taking the lead position. Probably if the youths had something to engage them, they would leave the business of stealing human beings in spite of the huge financial returns in so short a period and concentrate in more sustainable engagements. Ubong (2002) holds the opinion that encouraging the persons in the NDR to go into private business is more sustainable than even the Poverty Alleviation Programme which has been but a palliative on poverty. It is critical for Nigeria to recognize the special case of the NDR with respect to the difficult physical terrain and the effect of oil exploitation and exploration on the land and the people. 


\section{The Way Forward}

Some of the approaches towards entrepreneurial nationhood for Nigeria are discussed hereunder. The range from the broader issue of an incisive review of the national policy framework to more specific issues in specialized areas. It is important to start something in spite of prevailing circumstances.

\section{Review of the National Policy on Education}

Evidently, the best approach to entrepreneurial nationhood for Nigeria is through entrepreneurship education that cuts across the entire spectrum of the education system from primary school to university as well as in the informal system. Actualizing this will imply a definitive national philosophy of education that emphasizes self-reliance with entrepreneurship at the core. Professor J. D. Okoh has also made a national call to Nigerians to orientate their minds to the "The risk of an educational system without a philosophical base" (2005). Ubong (2012) has therefore suggested a review of the National Policy on Education (on-going, by the Nigerian Educational and Research Council, NERDC) towards new national goals on education that can be actuated as follows:

i) Teaching and practice of entrepreneurship at all levels of the education system, with the practical aspect expressed though vocational subjects at the primary and secondary school levels. At the tertiary level, the curriculum of all courses should include key aspects of entrepreneurship as all courses have the potentials for business development. It is pertinent to point out that poetry is part of the curriculum in medical schools as it has a bearing with medical practice in spite of the fact that a prima facie case would put the two subjects poles apart.

ii) Use of English Language as the first medium of instruction from pre-nursery whiles the mother tongue should be taught as a subject. It is the opinion of this writer that Nigeria's number one challenge in the education sub-sector is English Language (Ubong, 2009). The mother tongue (MT or LI or whichever), should be taught for purpose of group consciousness and integration. No child should be allowed to forget his or her roots, but for educational purposes, English Language must necessarily be taught and taught properly from the child's first day at school. The Nigerian child should be able to think and reason in English quite early. This is the path of realism if Nigerians are to play the field appropriately and optimally in the $21^{\text {st }}$ century and beyond. The NPE of the State of Singapore has the very first aim of education as being to give children 'a good grasp of English Language.' (Ministry of Education, Singapore, 2005). Mother tongue and Mathematics take the second position. Can we compare Singapore (one of the Asian Tigers) with Nigeria? In spite of its importance in the educational system and in national life, the standard of spoken and written English in Nigerian schools is appalling. There is therefore an urgent need for a special programme for the development of teachers of English Language in Colleges of Education and Universities for the foundation levels of the educational system. This would involve tuition-free programmes with special allowances to encourage the students.

\section{Appropriate Technology for Accelerated Growth}

As this presentation winds down, the most pertinent question that should agitate the mind is, given the fact that developing countries are operating in a century where technology is virtually everything, from food to health, from marriage to worship, from delivering a baby to burying a centenarian, from exploring the depths of the earth to the entire galaxy, what approach should Nigeria use? A colleague was in India recently for medical reasons. This developing country, currently regarded as 'medical Mecca,' has since done away with the traditional scalpel in performing surgery. In the case of cancer for instance, while the most sophisticated 
laboratories in the USA is still battling for a cure and the Venezuelan President succumbed, Indian specialist hospitals we are told, aggregate cancer cells from any part of the body to one location, then put in a tube and bring out a lump, leaving the patient without the tale-tale long scar that tells of the surgeons blade and weeks of mind-bending pain. Should the 'poorer' developing countries go hop-step-and-jump to that level?

In a paper I presented at the Nigerian Academy of Education Conference in 2003 at the University of Port Harcourt, I suggested that typewriters must be abandoned in favour of computers. A Professor in the group requested to know if my village (Oboyo Ikot Ita in Akwa Ibom State) enjoys electricity supply "24/7." The paper simply fell apart at that stage as the bottom had been cut off. When I remember the fragmented pieces of land in my village of which half has currently been sliced of courtesy of the Federal Ministry of Niger Delta Affairs that has acquired half of the village for a housing estate that will benefit only the upper class of our nation, the idea of mechanized agriculture becomes a pipe dream. What, then, is the way forward if entrepreneurship is to play the catalytic role by sitting on the driver's seat for accelerated economic development?

In a paper presented at the United Nations $2^{\text {nd }}$ World Conference on Technology and Development at the Ecolé Polytechnic de Lausanne, Switzerland, the following conclusion was drawn:

Results revealed the perception of those currently using modern technology: cutting edge technology would aid the development of Nigeria - used here as a typical poor country - yet, abandoning local technology would reduce the speed of economic development. Conversely, improving local technology would accelerate economic development. The paper sees appropriate technology for accelerated socio-economic development as essential technology defined as basic technology that characterizes a system or people's way of doing particular things. Poor countries would be better served if local technology is moved upwards in a pyramidal form. At present, the paradigm is that of an inverted pyramid where cutting edge technology is planted in virgin locations that have no base. In essence, the starting point in technology transfer from North to South should be the determination of the acceptance-rejection framework of the beneficiaries through research; and development effort should be holistic, encompassing economics, sociology, psychology, education, and technology.

In the computer cum information age where all of life virtually revolves around modern technology, we need technology; however, we can start with what we have and grow. No doubt we cannot do without technology. I also argue that entrepreneurship may not be the panacea, but it is the best starting point.

\section{Teacher Quality}

Teacher quality should be improved constantly through long and short courses in institutions and organizations. These could be part time or full time, in-plant or off-plant (Ubong, 2003) and through practicum (Ubong, 2002).

\section{Entrepreneurship Development}

Under entrepreneurship for women, the issue of entrepreneurship development was discussed; entrepreneurship development is a complex of activities in a process from identification through training and provision of support facilities to monitoring, evaluation and follow-up support or mentoring. There is the crucial need for the right environment that would promote fecundity and catalyze action. The School of Business Education of this College has this semester commenced a new approach to business education practicum: students are encouraged to develop products and services of interest to them with the aim of 
getting them into long term engagement in that product or service as entrepreneurs. Who knows, we may one day have the Bill Gates of Microsoft fame; the Steve Jobs of Apple computers fame; the Mark Zuckerberg of Facebook fame, all in their twenties and in school when they first developed their products that the world cannot do without now. We are aware, and are proud to mention that students of the Department of Chemistry of this College successfully developed a novel solution for battery charging. Others built a prototype of a crude oil refinery. These require encouragement, reason I had earlier said something about the triple-helix model which does not appear to be available in Nigeria at present.

\section{Entrepreneurship Framework Conditions (EFCs)}

GEM has outlined ten conditions that can promote entrepreneurship development in a society. These are: (1) Financial Support (2) Government Policies (3) Government Programmes (4) Education and Training (5) Research and Development Transfer (6) Commercial, Professional Infrastructure (7) Internal Market Openness (8) Access to Physical Infrastructure (9) Cultural and Social Norms (10) Intellectual Property Rights Protection. These conditions can be made possible in Nigeria to ensure that the nation works towards entrepreneurial nationhood.

\section{Business Size}

While one would wonder whether our argument that women be not consigned to small and micro businesses is about to be countered, we argue that starting small is better. Given the level of our technology and business knowledge and other resources, to start small and grow big is more ideal. Nigeria would not be out of sync with the experiences of other countries in tis reard. Cambieri (2011) submits that "Family businesses are the backbone of Italy's economy." Many of the big names today started off as small scale family businesses; these include Pirelli and Olivetti among others. In the USA, small businesses remain the bedrock of this world's largest economy, reason the agency, Small Business Administration is directly under the Presidency and the US President appoints the Chief Executive of that agency.

\section{Planning}

We may wish to take our minds back to the era of the military rulership in Nigeria. The Military Governor of Rivers State, Police Commissioner Fidelis Oyakhilome started a scheme he tagged School to Land Programme. This was designed for young people in schools and out of school youths. It was a successful programme until the fields were ripe and harvest was due. It was then that the Governor went in a motorcade to the Projects Development Agency (PRODA) at Enugu to seek information on ways and means of handling the bumper harvest from the youth farms.

This was, and sadly, is still not a surprise in a country where implementation of projects takes off before thorough planning (Ubong, 2001) has decried for instance, execution of the Universal Basic Education (UBE) programme before planning was even thought of. Agriculture, and indeed all of businesses make sense in the context of sales. It is an unwise investment if products of production facilities are in the store to gather dust, be destroyed by scavengers, and in the case of agri-business, rot away. This is why Ubong and Oguzor (2003) made a call for a review of the national policy on agricultural products marketing boards in Nigeria. The marketing boards had their heydays in the 1970s and as is with most government programmes in Nigeria, fizzled away. The boards were abolished and replaced with nothing. This might be one reason the rubber estate at Akamkpa, Cross River State was shut down after more than three decades of very successful operations because a Military Governor took over the export of rubber sheets that was at that time experiencing a boom in the world market. He took rubber sheets on credit, sold, and never paid money to the company. Over three thousand workers had to get back to the job market. 


\section{Summary and Conclusion}

This paper argues for a positioning of entrepreneurship as the locus of development effort at the national level. Although in a globalized world academic thinking should be universal, Nigeria is used as focus with the understanding that the position herein is applicable elsewhere particularly in developing countries which should better be described as poor countries, or at best, the old but more appropriate term 'less developed' countries. Describing them as 'growing' countries would probably tell a better story, only that one has no idea when they will mature - if ever. The paper holds the opinion that for rapid and sustained national development in Nigeria and indeed, poor countries, entrepreneurship should be placed at the driver's seat.

\section{References}

Acs, Z. (2006). How is entrepreneurship good for economic growth? Innovations. Winter. 97-107.

Ahiauzu, A. (2010). Entrepreneurship and economic development in Nigeria: The way forward. In A. Ahmed and S. Nwankwo (Eds.). Achieving sustainable development in Africa (pp. 278-296). London: WASD.

Ball, D. A., McCulloch, Jr., W. H., Frantz, P. L., Geringer, J. M., Minor, M. S. (2002). International business: The challenge of global competition (8 $8^{\text {th }}$ ed.). Boston: McGraw-Hill Irwin.

Boserup, E. (1990). Population, the status of women, and rural development. In G. McNicoll and M. Cain (Eds.). Rural development and population: Institutions and policy. Population and Development Review. Oxford: Oxford University Press.

Bunders, J. F. G; Broerse, J. E. W; Zwekhorst, M. B. M. (1999). The triple helix enriched with the user perspective. Journal of Technology Transfer. 24 (2 \&3), 235-246.

Cambieri, G. (2011). Family Businesses are Italy's Economic Engine but Face Governance Challenge. Retrieved March 08, 2013 from http://www.campdenfb.com/article/family-businesses-are-italys-economic-engine-face-governancechallenge

Castle, E. B. (1965). Principles and practice of education. Nairobi: Longmans.

Chan, A. Entrepreneurship: What does it really mean? Retrieved on August 09, 2005 from http://www.entrepreneurnewz.com/entrepreneurnewz_19_20050308_EntrepreneurshipWhatDoes

Cable News Network (2013). Leading women. Retrieved January 30, 2013 from http://edition.cnn.com/video/\#/video/business/2013/02/12/leading-women-angeliki-frangou-naviosshipping.cnn?iref=allsearch

Cable News Network (2013). Leading women. Retrieved March 05, 2013 from http://edition.cnn.com/video/\#/video/business/2013/01/01/leading-women-guler-sabanci.cnn/

Dejardin, M. (2000). Entrepreneurship and economic growth: An obvious conjunction?" Publication series. The Institute for Development Strategies, Indiana University.

Esene, R. A. (1997). Managing teaching learning process for business education. Nigerian Association for Business Education. Agbor: Royal Pace Publication.

Federal Republic of Nigeria (2004). National Policy on Education.Lagos: NERDC Press.

Henderson, J. (2007). Understanding rural entrepreneurs at the country level: Data challenges. Paper presented at the Frameworks for Entrepreneurship Research in Food, Agriculture, and Rural Development Workshop, Kansas City, October 18.

Hisrich, R. D. and Peters, M. P. (1998). Entrepreneurship. (4th ed.). Boston, Massachusetts: Irwin/McGraw-Hill.

Ito, T. (1998). What can developing countries learn from East Asia's economic growth? In B. Pleskovic and J. E. Stiglitz (Eds.) Annual World Conference on Development Economics.(p.187). Washington, D.C: The World Bank.

Kankonen, E and Nieminen, M (1999). Modeling the triple helix from a small country perspective: The case of Finland. Journal of Technology Transfer. 24 (2\& 3), 173-183.

Klofsten, M; Jones-Evans, D and Scharberg, C. (1999). Growing the Linkoping technopole: A longitudinal study of triple helix development in Sweden. Journal of Technology Transfer. 24 (2\&3), 125-138. Retrieved on July 17, 2006 from http://www.nal.usda.gov/ttic/JTechTransferTOC

Kneller, G. F. (1965). What is philosophy of education? London: Macmillan Publishers. 
Longley, R. (2013). Why small businesses fail: SBA Retrieved, March 08, 2013 from http://usgovinfo.about.com/od/smallbusiness/a/whybusfail.htm

Mautner, T. (2000). The penguin dictionary of philosophy. London: Penguin Books Ltd.

Ministry of Education, Singapore (2005). Primary education. Retrieved, August 05, 2005, from http://www.moe.gov.sg/corporate/primary_01.htm

Naude, W. (2011). Entrepreneurs and economic development. In W. Naude (Ed.). 'Entrepreneurship and Economic Development'. Retrieved, June 022011 from http://www.wider.unu.edu/publications/books-andjournals/2011/en_GB/Entrepreneurship-Econ-Devl.

Nickels, W. G., McHugh, J. M. and McHugh, S. M. (2002). Understanding business. (6 ${ }^{\text {th }}$. Ed.). Boston: McGraw-Hill Irwin.

Nwosu-Izuwah, L. U. (1999). Gender issues in curriculum (subject specialization) in higher educational institutions in Nigeria, Journal of Quality Education. 104.

Obi, C. A. and Ali, A. (1995). Influence of age on women managers' perception of some affective work skills. Journal of Quality Education. 2. 1-2.

Oguzor, N. S; Nwokocha, A. C and Ubong, B. (2004). Information and communications technology in teacher education. The Colloquium - A Multidisciplinary Thematic Policy Journal. 2 (2).

Oranu, R. N. (1998). Foreword to the essentials of entrepreneurship education in technology and art. In N.P.M Esomonu (Ed.). The Essentials of Entrepreneurship Education in Technology and Art. (p.x). Umunze: Federal College of Education (Technical).

Oyodele, J. F. (2000). Business education in Nigeria: The challenge for the $21^{\text {st }}$ century. Business Education Journal. III (3). 2.

Paul, S; Ickis, J. C and Levistsky, J. (1989). Educating Managers for Business and Government: A Review of International Experience. A World Bank Discussion Paper. Washington, DC: The World Bank.

Peters, R. S. (1980). Ethics and education. London: George Allen \& Unwin.

Renjith, R. P. (2009). Role of entrepreneurship in econ development. Retrieved June 10, 2011 from www.indiastudychannel.com.

Strom, R. J. (2011). Entrepreneurship and economic development. Retrieved March 10, 2011 from http://www.wider.unu.edu/publications/newsletter/articles-2011/en_GB/04-2011/

Thomas, A. (1999). The Cynon Valley project: Investing in the future. The Hague: Bernard van Leer Foundation.

Thurik, R. (2009). Entrepreneurship, economic growth and policy in emerging economies. Research Paper No. 2009/12. United Nations University (UNU)/The World Institute for Development Economics Research (WIDER).

Ubong B. (1999). Street trading, child education, and the parental dilemma. Institute Journal for Education and Development (IJERD). 1(1).

Ubong, B. (1999). Nigerian education, management education, and training in international perspectives: A comparative analysis. Journal of Pedagogy and Development. 6(1).

Ubong, B. (2000). Science, technology, and mathematics (STM) education for sustainable industrialization in Africa. In M. A. G. Akale (Ed.). Science, technology, and mathematics education for sustainable development in Africa. Proceedings of the $43^{\text {rd }}$ Annual Conference of Science Teachers Association of Nigeria (STAN), Lagos: Heinemann Educational Books (Nig.) PLC.

Ubong, B. (2000). Entrepreneurship education for scientists: A new emphasis in tertiary institutions. Journal of Vocational and Adult Education. 2 (1).

Ubong, B and Wokocha, A. M. (2000). Internally generated funds for effective management of schools: A systems model for tertiary institutions. Occasional Publication. Series No.1.Omoku: Federal College of Education (Technical).

Ubong, B. (2001). Business as a vocation: Entrepreneurship development for women through business education. International Journal of Research in Science and Education. 1(1).

Ubong, B. (2001). Attitude of female science students towards private business as a vocation and the role of business education. In O. O. Busari (Ed.). Women in science, technology, and mathematics education in Nigeria. Proceedings of the $42^{\text {nd }}$ Annual Conference of the Science Teachers of Nigeria (STAN). (pp 403-406). Lagos: Heinemann Educational Books (Nig) Plc.

Ubong, B. (2001). Business as a vocation: Entrepreneurship development for women through business education. International Journal of Research in Science and Education. 1 (10). 36-41. 
Ubong, B. (2001). The planning component in the universal basic education scheme. In P.O. Nwaokolo; G.C. Igborbor and G.C. Nduka. (Eds). Universal basic education in Nigeria: Concepts, issues and prospects. Asaba: Federal College of Education (Technical).

Ubong, B. (2001). Attitude of female science students towards private business as a vocation and the role of business education. In O. O. Busari. (Ed.). Women in science, technology and mathematics education in Nigeria: $42^{\text {nd }}$ annual conference proceedings 2001. Science Teachers Association of Nigeria (STAN). Lagos: Heinemann Educational Books (Nig.) Plc.

Ubong, B. (2001). Sustainable poverty alleviation in Nigeria through entrepreneurship education for scientists and technologists. In T. A. G. Oladimeji; O.T. Ibeneme; O. M. Adesope; M. A. Ogunyemi and H. M. Tukura. (Eds.). Technology education and poverty alleviation in Nigeria. Lagos: Nigerian Association of Teachers of Technology (NATT).

Ubong, B. (2002). The Nigerian child, his education, and the Nigerian labour law. NCEMA Policy Analysis Series. 8 (2).

Ubong, B. (2002). Towards more business courses for engineers, technologists, and technicians. The Nigerian Teacher Today: A Journal of Teacher Education.10 (1).

Ubong, B. (2002). Business development in the Niger Delta through education and related factors. In R. A. Wokocha (Ed.). Development rights issues in the Niger Delta. Port Harcourt: Rivers State University of Science and Technology.

Ubong, B. (2002). Business teacher education curriculum: A case for review. In B. Ubong (Ed.) New perspectives in business education curriculum (A book of readings). Business Education Series 1.

Ubong, B. (2002). Improving the quality of business teachers in tertiary institutions: A refocus through the practicum approach. In S.O. Oriaifo, R.O.E. Nwaokolo, \& G.C. Igbogbor (Eds.). Refocussing education in Nigeria. Abraka: Faculty of Education, Delta State University.

Ubong, B. (2002). Business development in the Niger Delta through education and related factors. In R. A. Wokocha (Ed.). Development rights issues in the Niger Delta. Port Harcourt: Rivers State University of Science and Technology.

Ubong, B. (2002). Business teacher education curriculum: A case for review. In B. Ubong (Ed.) New perspectives in business education curriculum (A book of readings). Business Education Series 1.

Ubong, B. (2002). Improving the quality of business teachers in tertiary institutions: A refocus through the practicum approach. In S.O. Oriaifo, R.O.E. Nwaokolo and G.C. Igbogbor (Eds.). Refocussing education in Nigeria. Abraka: Faculty of Education, Delta State University.

Ubong, B. (2003). The Nigeria certificate in education home economics curriculum: Need for inclusion of business education courses. Omoku Journal of Women in Colleges of Education. 1 (1).

Ubong, B. (2003). The gender controversy, biblical account, status of women, and their empowerment. The Nigerian Journal of Research and Production. 2 (1).

Ubong, B. (2003). On-the-job training for organizational development and industrial apprenticeship: Issues, forms, and challenges. African Management Review. 1 (1 \&2). [Published in Addis Ababa, Ethiopia].

Ubong, B. (2003). The gender controversy, biblical account, status of women, and their empowerment. Nigerian Journal of Research and Production. 2(3). 113-121.

Ubong, B. (2004). The participation of teaching staff in the development of businesses in tertiary educational institutions. The Colloquium - A Multidisciplinary Thematic Policy Journal. 1 (1).

Ubong, B. (2004). Women and peace. Paper presented at the Campaign for Peace by Women Groups in Ogba/Egbema/Ndoni Local Government Area (ONELGA), Rivers State, at the Civic Centre, Omoku, October 11.

Ubong, B. (2005). Towards engendering communal peace through entrepreneurship development programmes for women. Journal of Women in Colleges of Education (JOWICE). 9. 460-466.

Ubong, B. (2005). Strategic planning for improvement of standards in business education in Nigerian tertiary educational institutions. Journal of Education in Developing Areas. 14.

Ubong, B and Oguzor, N. S. (2005). Research and funding of research in tertiary educational institutions in Nigeria. Nigerian Journal of Professional Teachers. 1 (1).

Ubong, B. (2005). Towards engendering communal peace through entrepreneurial development for women. Journal of Women in Colleges of Education. 9.

Ubong, B. (2006). Transfer of technology as a catalyst for the economic transformation of developing countries. Journal of the National Association of Science, Humanities, and Education Research (NASHER). 4 (1). 
Ubong, B and Nyanabo, I. F. (2006). Entrepreneurship education for poverty alleviation among Nigerian youths. Trends in Educational Studies - Journal of the Institute of Education, University of Port Harcourt. 1 (2).

Ubong, B. (2006). Entrepreneurship capacity building in the universal basic education programme. Nigerian Management Review. 17 (1).

Ubong, B and Oriji, C. (2006). Women in science, technology, and information communication technology: Problems and prospects. Journal of International Gender Studies. 46-54.

Ubong, B and Oguzor, N. S. (2007). Vocational education and the development of adult learners in Nigeria through skills acquisition schemes. Bulgarian Journal of Science and Education Policy (BJSEP). 1 (1). [Published in Sofia, Bulgaria].

Ubong, B. (2008). E-commerce in Nigeria: Issues, problems, and prospects. Journal of Management and Enterprise Development. 5 (1).

Ubong, B., Oguzor, N. S and Wokocha, A. M. (2009). Educating people for food security to avoid food crisis: The case of developing countries. Bulgarian Journal of Science and Education Policy (BJSEP). 1 (3). [Published in Sofia, Bulgaria].

Ubong, B. (2009). The language threat in the Nigerian educational system: Can it be confronted? Nigerian Journal of Empirical Studies in Psychology and Education.

Ubong, B and Wokocha, A. M. (2009). Continuous assessment, practicum, and the quality of business education programmes in Nigeria. Review of Higher Education in Africa. 1 (1). [Published in USA].

Ubong, B. (2009). Globalization and entrepreneurship education in developing countries. Journal of Technical and Vocational Education. 1.

Ubong, B. (2012). Essential technology for development: Towards a pyramidal paradigm. $2^{\text {nd }}$ International UNESCO Chair Conference on Technology and Development. Ecole Polytechnic Fedéralé de Lausanne (EPFL), Lausanne, Switzerland, May 29-31.

Ubong, B. (2006). Is technology transfer the shortest route to economic transformation of developing countries? Paper presented at the $3^{\text {rd }}$ Annual National Conference of National Association of Science, Humanities, and Education Research (NASHER), Benue State University, Makurdi. May 24-27.

United Nations (1994). International conference on population and development: Program of action. New York: United Nations.

United Nations Children's Fund (2000). Millennium development goals. Retrieved on September 09, 2006 from http://www.unicef.org/mdg/

United Nations Children's Fund (2009). UNICEF Nigeria - Overview: the Nigerian situation. Retrieved March 10, 2013 from www.unicef.org/nigeria/1971_2199.html

United Nations Population Fund (2005). State of the world population. Retrieved on May 15, 2006 from http://www.c.org/swp/2005/images/e_indicators2.pdf

United Nations Development Programme (2009). Human development - Human development Reports. Retrieved on October 22, 2010 from http://hdr.undp.org/en/humandev/

University of Nigeria (2010). Faculty of education: Faculty information handbook 2010/2012. Enugu: Masterstroke Publications.

Wolfensohn. J. D. (2000). A time for action: Placing education at the core of development. Adult Education and Development. 55. 67.

Wokocha, A. M. (1995). Women education and community development in Nigeria: An overview. Journal of Educational and Vocational Studies. 1 (1). 133. 
ISSN 2039-2117 (online)

ISSN 2039-9340 (print)
Mediterranean Journal of Social Sciences

MCSER Publishing, Rome-Italy
Vol 4 No 16

December 2013 